\title{
Implementation of Justice Principles in Competitive Business Competition
}

\author{
Osgar S Matompo \\ Faculty of Law \\ University of Muhammadiyah \\ Palu, Indonesia \\ doktor.osgar@gmail.com
}

\begin{abstract}
Unhealthy competition occurs because of the existence of few producers or because the market structure is pure monopoly (no competition). The actors in their business activities bear a dual purpose in addition to fight to obtain some benefits also to meet the needs of the community about the availability of goods and services. This paper is aimed at describing the implementation of justice principles in regulating competitive business. The type of study is a normative legal study traced by statute and conceptual approaches. Data were obtained through the literature study and the book of laws governing the justice principles. Results showed that the function of law in realizing business competition can be effective if the rule of law is obeyed. The nature of the business competition law regulatory function is the legal capability of realizing market structure, market conduct and market performance that are not easily distorted and monopolistic so that the market conditions remain perfect.
\end{abstract}

Keywords-fair principles; business competition; competitive

\section{INTRODUCTION}

Currently, Indonesia has been in ASEAN Economic Community (AEC). AEC emerged from the desire of ASEAN countries to actualize ASEAN as solid and taken into account economic area. The goals of AEC are the free flow of goods and services, skilled labors, and more free investment flow. One of significant roles in AEC is the businessmen.

Any knowledge and theory which become reference in business activities is not regardless of moral and legal values. However, it cannot be denied that in the globalization till AEC era, behaviors of businessmen tend to ignore moral and legal values that is applied in community. It results the legal principles of fair competition "burried" and generating fraudulent business competition that adorns power struggle in any business chance personally and legal entity that is uncontrolled. So that the market structure and performance distorted and monopolized.

The business competition, ignoring the weak society from both capital and creativity which becomes a character of most Indonesian people, has been a weakness of Business Competition Constitution. This happens as the producer is simply a fraction of business actors which is called perfect market. Different from the unfair market, an attempt of producers will affect the market in form of offer and demand.
Unfair competition occurs of the less number of producers or the monopolized market structure (no competition). Businessmen's efforts to obtain benefits. Business actors, in their business activities, carry double goals on namely besides obtaining benefits also meeting the needs of people due to goods and services supply. Their attempt to obtain benefits will be achieved if they have skill, proficiency and reliable ability, and they are able to compete with other businessmen fairly. The proficiency is in relation to knowledge mastery and economic theories, because a business management needs an economic approach.

Considering the situation forces us to take a close look and reorganized business activities in Indonesia since the enactment of Constitution number 5, 1999 concerning Monopoly Practice Prohibition and Unfair Competition which is based on free market, Indonesia market has been in ownership of foreign and big financiers that it does not take side on this nation and its' people who dominantly are small traders with less innovation and unprotected from competition.

This, absolutely, contradicts to strategic role of legal in economic development that is in duty to maintain and create safeguards so that the implementation of economic development will not compromise the rights and interests of the weak. Sritua Arief revealed that there is a group of economists who argue that "economics is a value free science" [1]. This view tends to penetrate the minds of some business actors, so that there are business actors who think that the relationship between business and ethics or moral values of the business actor cannot be a guide in business competition.

It should be admitted that economic activity is inseparable from the competition among business actors, it is a requirement for the implementation of market economy, so that competition among business actors will be more open. Competition is a must to improve efficiency, production, market transparency and commensurate advantage earning. The required competition in the business world is the proportional competition which can guarantee the realization of a perfect market system.

Building on this, this paper is aimed describing the implementation of justice principles in competitive business competition. 


\section{METHOD}

This study is a normative study to explore the legislation implementation, particularly on business competition. It was conducted using conceptual and statute approach to law. Data were obtained from observation and library study which included collecting related literature to the regulations and implementation of justice principles in economy field. The data is collected and analyzed in Indonesia. Legal materials were also collected in supporting the data accuracy. The analysis of the data was carried out by applying qualitative method. The data is presented in qualitative descriptive method.

\section{RESULT AND DISCUSSION}

\section{A. Legal Functions in Business Competition}

Efforts to create a conducive business climate and competitive and fair business competition, theoretically, there should be a legal system that supports the aforementioned objectives through the establishment of a set of provisions on the prohibition of monopolistic practices and unfair business competition. The presence of the provisions of the legislation is a legal norm which carries a certain function that cannot be separated from the function of law in general.

Some legal experts have provided a review of the legal functions in society. For example, Achmad Ali distinguishes legal functions into five categories namely.

- Legal function as a tool of social control.

- Legal function as a tool of social engineering.

- Legal function as symbol.

- Legal function as a political instrument.

- Legal function as integrator [2].

Furthermore, Hoebel in Satjipto Rahardjo, argued that there are 4 functions of legal, they are:

- Formulating relationships among community members.

- Taming the powers which operating within society by directing them to the maintenance of order by allocating authority.

- Settlement of arising disputes.

- Redefining relationships among individuals and groups when life conditions change [3].

Although there are differences in the formulation of the two opinions of the legal expert, from both of them can be seen that legal functions can be, such as, as a tool of social control and a tool of social engineering. In relation to these two functions, the function of law as a means of social control is the law of duty to keep the society in the behavior patterns that have been accepted by it. In such a role the law maintains only what has become a fixed and accepted thing in society.

Unlike the function of law as a means of social control, if the function of law is as a means of social control, then the law is not only intended to maintain the patterns of behavior that have been accepted by the community, but it is intended to cause change. As stated by Satjipto Rahardjo that the law is not only used to reinforce the patterns of habits and behavior contained in society, but also to direct to the desired goals, to eliminate the habit which it considers to be incompatible with the demands of the development of its society, creating new behavior patterns and so on.

The description of the function of law as a tool of social engineering is also proposed by Soerjono Soekanto [4] that law is a tool to change society, in the sense that law may be used as an agent of change. Legal function as agent of change or pioneer of change means a person or a group of people who gain the trust of the community as the leader of one or more community institutions. Pioneers of change of community leaders in transforming social systems and in doing it are caught in the pressures to make other changes. A desired or planned social change is always in the control or oversight function of the pioneer of such change.

The presence of legal provisions of business competition in addition to function as a tool of social control is also expected to function as a tool of social engineering. If in the past years the behavior patterns of business actors tend to lead to fraudulent competition, then with the existence of the provisions of competition law, the pattern of fraudulent competition behavior will end and change towards the expected pattern of behavior.

The business competition law functions as described above are expected to be effective. If the rules of law are adhered to or used, then the rule of law functions effectively in order to grow a healthy business competition. Conversely, if the rule of law is not adhered to or not implemented properly, then the rule of law concerned can be seen as failing to realize its function. The quality of obedience or compliance with the rule of law varies. As mentioned by H.C. Kelman in Achmad Ali that there are three types of legal compliance of citizens, namely:

- Someone is obedient to the law in order to avoid getting punishment as legal sanctions. Therefore, his obedience is not due to believe in the purpose of the rule of law. This kind of obedience is compliance.

- Someone obeys the law so that his good relationship with those who are authorized to apply the law remains good. This type of obedience is identification.

- Someone obeys the law because it is intrinsically appropriate to the value it embraces. This type of obedience is internalization [2].

Taking into account the level of compliance quality of law described, then the obedience of the law in a form of internalization is what is expected in the legalization, because compliance is based on a culture of law that is believed intrinsically. According Soerjono Soekanto, for a rule of law really works, it can always be returned to at least four factors:

- The rule of law or the rule itself.

- Officers enforcing the law.

- The facilities expected to support the implementation of the rule of law. 
- The existence of people affected by the scope of the regulation [5].

The above view is in line with Lawrence M. Friedman's opinion that a legal system consists of three components: (1) elements of the legal structure, (2) elements of legal substance and (3) elements of legal culture [6]. These three components of the legal system are interdependencies. This means that the components of the structure and legal culture will tend to affect the function or not a legal substance. It is appropriate that C.F.G Sunaryadi Hartono argues that Law Number 5 Year 1999 will only be a dead letter and has little meaning, if it is not supported by other elements that are integral parts of a good legal system:

- Other regulations which are closely related to monopolistic practices and unfair business competition, such as rules of contract law, corporate law, against law behavior and various regulations that must replace the Civil Code.

- Institutions or legal institutions must ensure the enforcement of Law No.5 of 1999, such as the Business Competition Supervisory Commission which is completely independent and not influenced by government elements.

- The existence of clean and efficient government, which carries out the granting of licenses in a timely manner without referring to other agencies or officials to serve the persons or entrepreneurs who need the permits concerned (debirocratization).

- The existence of law enforcement officers such as clean and efficient officers and prosecutors, who need not be bribed to serve those who report unlawful practices, and which do not deflect the company, so that the reporter is being pursued by legal officers.

- The most crucial is the state of our judicial system that tends to bend the principles of law universally applicable, so that the legal certainty and justice further out of the reach of seekers of justice [7].

\section{B. Principles for Achieving Fair Business Competition}

That it must be acknowledged in economic activity is inseparable from the competition between business actors, and thus is a requirement for the implementation of market economy, especially in the era of Asean Economic Community (AEC) which demands free market economic system, so that competition among business actors will be more open. Sometimes business competition is a fair competition, but it can also happen where business actors in order to gain the maximum benefit, do unfair competition. To avoid unfair competition, it is necessary to apply the principles of business competition:

1) Principles of honesty and not against the law: Fair competition is the competition among service providers that is done honestly and not against the law. In Law no. 5 Year 1999, it has been explained about the understanding of healthy competition principle, they are:
- The equal position between service user and service provider is admitted.

- Provisions on the principles of transparency in the selection process and determination of service providers is fulfilled

- The existence of opportunity for participation in every stage of fair competition for the service provider in accordance with the required capabilities and conditions.

- The existence of documents that are clear and complete and well known by all parties and are binding.

If the principle of fair competition is actualized in the tender process, the service users will meet reliable service providers and have the ability to produce work within the specified time period and cost. On the other hand it is an effort to create a business climate that supports the growth and development of service providers that are increasingly qualified and able to compete.

The principle pf healthy competition has been elaborated in several laws and regulations. Article 22 and 23 of Law no.5 of 1999 has affrimed the form of prohibited acts for every business actor, namely:

(Article 22):

"Pelaku usaha dilarang bersekongkol dengan pihak lain untuk mengatur dan atau menentukan pemenang tender sehingga dapat mengakibatkan terjadinya persaingan usaha tidak sehat".

Business actors are prohibited from conspiring with other parties to regulate and or determine the winning bidder so as to result in unfair business competition.

(Article 23):

"Pelaku usaha dilarang bersekongkol dengan pihak lain untuk mendapatkan informasi kegiatan usaha pesaingnya yang diklasifikasikan sebagai rahasia perusahaan sehingga dapat mengakibatkan terjadinya persaingan usaha tidak sehat".

Business actors are prohibited from conspiring with other parties to obtain information of their competitors' business activities which are classified as confidential which can lead to unfair business competition.

Illegal acts for business actors are also reinforced in Article 55 of Government Regulation no. 29 Year 2000, that service users and service providers or among service providers are prohibited from conspiring to arrange and / or determine winners in public auctions or limited auctions resulting in an unfair business competition. The application of healthy competition principle above will positively influence the effort to eliminate inefficiency, monopoly, corruption, and collusion and nepotism practices. Thus, the application of this principle is not only beneficial to the service providers but also can minimize the chances of loss of the state.

2) The principle of openness: The principle of "openness" implies the availability of information accessible to service 
providers, thereby providing an opportunity for service providers to compete in an auction process. All provisions and information on the auction include technical administrative requirements, average means of evaluation, evaluation results, and determination of potential winners shall be open. By applying this principle, an auction process can not only be accounted administratively, but sociologically. It is said so, because citizens have the opportunity to correct the auction process if it turns out to be irregularities in its implementation.

Law No. 5/1999 on "Prohibition of Monopolistic Practices and Unfair Business Competition" as well as Law No. 18/1999 on "Construction Services" gives room for citizens to participate in supervising the orderly conduct of fair business competition. In article 38 paragraph 1 of Law No. 5 of 1999, it has been affirmed as follows:

Setiap prang yang mengetalmi telah terjadi atau patut diduga telah terjadi pelanggaran terhadap undang-undang ini dapat melopork-an secara terlulis kepada Konasi dengan keterangan yang jelas tentang telah terjadinya pelanggaran dengan menyertakan identitas pelapor.

Any person who has experienced or has reasonably suspected violations of this law may report in writing tp Konasi with a clear explanation of a violation by including the indentity of the complainant.

Similarly, in Article 29 paragraph (1) and (2) of Law no. 18 of 1999, it is affirmed as follows:

Conducting supervision to actualize the orderly implementation of construction services.

Obtaining adequate reimbursement for any direct losses experienced as a result of construction operations.

3) Principle of fairness: The fair principle in business competition is a legal principle and must be upheld in a legal state. This principle relates to the principle of equality before the law (e.g., equality before the law), egalitarian principles or the principle of non-discrimination. In the theory of antimonopoly law, it is known that some kind of price discrimination is prohibited as stated by Munir Fuady [8], as follows:

The principle of fairness in business competition implies giving equal treatment to all potential service providers and not leading to profit a particular party in any way or reason. The principle of fairness in business competition is a legal principle and must be upheld in a legal state. This principle relates to the principle of equality before the law, egalitarian principles or the principle of non-discrimination. In the theory of antimonopoly law, it is known that some kind of price discrimination is prohibited as stated by Munir Fuady, as follows:

- Primary price discrimination.

- Secondary price discrimination

- Common price discrimination.

- Geographical price discrimination.
- First-degree price discrimination

- Level two price discrimination.

- Directly Price discrimination

- Indirectly Price discrimination.

In the religious norms, there are several verses in the Qur'an about benefits and justice which are the core of Islamic Law, some of them are in verses:

An-Nissa article 58 "Indeed, Allah commands you to render trusts to whom they are due and when you judge between people to judge with justice. Excellent is that which Allah instructs you. Indeed, Allah is ever Hearing and Seeing.

An-Nissa article 135" O you who have believed, be persistently standing firm in justice, witnesses for Allah, even if it be against yourselves or parents and relatives. Whether one is rich or poor, Allah is more worthy of both. So follow not [personal] inclination, lest you not be just. And if you distort [your testimony] or refuse [to give it], then indeed Allah is ever, with what you do, Acquainted.

Al-Maidah article 8 " $\mathrm{O}$ you who have believed, be persistently standing firm for Allah, witnesses in justice, and do not let the hatred of a people prevent you from being just. Be just; that is nearer to righteousness. And fear Allah; indeed, Allah is acquainted with what you do [9].

4) Principle of proportionality competition: In the era of ASEAN Economic Community (MEA) nowadays, economic activities are becoming more intense and widespread reaching all parts of the world and having the widest range of human activities anywhere, distance and time are no longer a barrier to economic activity. It should be recognized, economic activity is inseparable from the competition between business actors, and it is a requirement for the implementation of market economy, so that competition among business actors will be more open.

Competition is a must in improving efficiency, production, market transparency and earning a commensurate advantage. According to the legal aspect, competition is a right, therefore it should not be annihilated by another party.

When described, the elements of the competition act are as follows:

- Some businessmen

- In the same line of business;

- Together running the company;

- In the same marketing area;

- Each tries harder than the other; and

- To gain the most profit [10].

A well-functioning business competition enables market participants to perform autonomously in their respective business fields and specifications of each business actor and it can determine their business actions regardless of interference or influence of other business actors. So it depends entirely on 
the market mechanism proportionality. Finally, with the increasingly tight competition, it will lead to proportionalism in business competitions which are competitive and fair.

Furthermore, in relation to the notion of "the principle of proportional competition, I shall describe in advance the "principle" or "basics" which in Dutch is called "beginsel" [11] or "principle" [12] or in Latin called "principium" [13] ("primus" means first and "capera" means taking or capturing), lexically means something that is the foundation of thinking or acting or truth which is the basic of thinking, acting and so on.

To distinguish between them both, it can be traced from the lexical meanings between the two terms, the meaning of "equilibrium" and "proportionality". In the dictionary the word "equilibrium" means balanced state (equal - weight, equilibrium, proportional, and worth) whereas the word "proportionality" or "proportional" in Big Indonesian Dictionary (KBBI) means in proportion, comparable proportional [14].

The principle of proportionality competition is competition or business competition conducted between business actors in accordance with the classification and qualification of business entities owned by each business actor.

Based on some explanations and principles, it is known that since the validity of the provisions of legislation related to the law of fair business competition, it has not been able to show a positive direction towards the creation of a harmonious condition among business actors in the management of production and service resources in the community. Business actors' behavior tend to conspire in the management of goods / services so that the philosophy of the provisions of legislation regulating the law of fair business competition is not achieved. In this connection, referring to several theoretical foundations, it can be used as a reference to reconstruct a healthy, competitive and fair legal system business competition through an analysis of related legal components through proportionality competition principle approach. This approach is indispensable because until now there has not been an analytical study of business competition law using the proportionality competition principle approach.

\section{CONCLUSION}

From this short and simple scientific oration I submit, there are some important notes to be drawn, among others: Firstly, the function of law in realizing business competition can be effective if the rule of law is obeyed. The nature of the business competition law regulatory function is the legal capability of realizing market structure, market conduct and market performance that are not easily distorted and monopolistic so that the market conditions remain perfect. Secondly, in order to realize the Perfect Market Law system, the principles of business competition required are Principles of Honesty and Not against the Law, Principles of Transparency, Principles of Fairness and Principles of Proportionality Competition.

\section{ACKNOWLEDGEMENT}

The author would like to thank all the parties who have helped and contributed in the writing of this article, both those who contribute in the form of funding and critical ideas. Hopefully this paper can be useful theoretically and practically for the addition and development of knowledge, especially in the field of legal science.

\section{REFERENCES}

[1] S. Arief, Teori Yang Murni Tentang Hukum, Alumni, Bandung. 1998, page 45 .

[2] A. Ali, Menguak Tabir Hukum, Chandra Pratama, Jakarta, 1996. Page 28.

[3] S. Rahardjo, Hukum dan Masyarakat, Penerbit Angkasa, Bandung, 1986, page 31 .

[4] S. Soekanto, Penemuan Hukum Sebuah Pengantar, Liberty, Yogyakarta, 1996, page 18.

[5] S. Soekanto, Faktor-Faktor Yang Mempengaruhi Penegakan Hukum, CV. Rajawali, Jakarta. 1983, page 30.

[6] L. M. Friedman, 501. American Law an Introduktion, Second Edition, Penerjemah oleh Wishnu Basuki, Penebit PT. Tatanusa, JakartaIndonesia. Page 34.

[7] C. F. G. S. Hartono, Pembangunan Hukum Ekonomi Indonesia dalarn Rangka Mewujudkan Perilaku Bisnis dan Persaingan Usaha Yang Sehat, Makalah.1999, page 15.

[8] M. Fuady, Hukum Anti Monopoli Menyongsong Era Persaingan Sehat, PT Citra Aditya, Bandung 1999, page 57.

[9] Benefit and Fairness become a core of Islamic law. This is actualized by the numbers of Al-Qur'an articles about Benefit and Fairness. Such as: An-Nisaa':58; An-Nisaa':135 dan Al-Maidah: 8

[10] H. Hanai, Persaingan Dalam Bisnis Ditinjau Dari Sudut Pandang Undang-Undang Nomor 5 Tahun 1999 Tentang Larangan Praktek Monopoli Dan Persaingan Usaha Tidak Sehat, accessed on http://gobagsodorpadhangnjingglang.blogspot.com/2012/06/persaingandalam-bisnis-ditinjau-dari.html

[11] W. V. Hoeve, Kamus Belanda-Indonesia, Ichtiar Baru van Hoeve, Jakarta, 1996, page 32.

[12] H. Campbell, Black's Law Dictionary, West Publishing Co.,St. PaulMinnessota, 1990, page 1193.

[13] L. Bagus, Kamus Filsafat, Gramedia Pustaka Utama, Jakarta, 1996, page 891-892.

[14] Tim Penyusun Kamus Pusat Pembinaan dan Pengembangan Bahasa Departemen Pendidikan dan kebudayaan, Kamus Besar Bahasa Indonesia, Edisi II, Balai Pustaka, Jakarta, 1995, page 373 